\title{
DAYA DUKUNG DAN POTENSI LAHAN UNTUK PENGEMBANGAN TANAMAN PANGAN DI KAWASAN SUB-DAERAH ALIRAN SUNGAI PANASEN KABUPATEN MINAHASA
}

\author{
Dolfie D. D. Tinggogoy \\ Jailani Husain \\ Sandra Pakasi
}

\begin{abstract}
The aims of this reserch was analyzing the carrying capacity of the land based on food crops productivity in Panasen sub-watershed areas Minahasa regency, Analyzing land suitability clases for food crops development in Panasen sub-watershed areas Minahasa regency, Knowing the vast potential of land that could be used for food crops development in Panasen sub-watershed areas Minahasa regency and Mapping the land potential at scale of 1: 50,000 for food crops development in Panasen sub watershed areas Minahasa regency. The research method is a survey method, methods overlay is used to create a map of a group of land based on slope maps, land use maps and soil maps. Method of matching (match) is used to determine the grade of land suitability and potential land area of each crop. Statistic methodis used for the carrying capacyti of agriculture land analyzing. The results of the research show that are the carrying capacity of agricultural land is $=2.93$. Rice equivalent is $2,93 \times 265 \mathrm{~kg} /$ person/year is 776, $45 \mathrm{~kg}$ of rice/person/year. Potential land for geared the development of food crops is a rice crops is 3095.10 ha which consists of land suitability classes S3wa ${ }_{2} r_{1}$ with total area of 1777.07 ha and class $\mathrm{S} 3 \mathrm{wa}_{2}$ with total area of 1.318 .03 hectares. a maize crops is 1.961,14 ha which consists of land suitability classes $S 3 w a_{1}$ is 755,52 ha and class $S 3 w a_{1} r c_{1}$ with total area of 1205.62 ha. The limiting factor is the heaviest average rainfall of $2357.2 \mathrm{~mm} /$ year $\left(w_{1}\right)$, and soil texture is sandy loam/agak kasar (rc 1$)$. a cassava crops is 1961,14 ha which consists of land suitability classes $S 2 w_{1,2}$ with total area of 755.52 ha and class S3tc with total area of $1205.62 \mathrm{ha}$. The limiting factor is the heaviest average rainfall of $2357.2 \mathrm{~mm} /$ year (wa 1 ), the number of consecutive dry months 1,41 months / years $\left(w_{2}\right)$, the average air temperature of $21.8^{\circ} \mathrm{C}$ (tc). a sweet potato crops is 1961,14 ha with land suitability classes S3wa. The limiting factor heaviest air humidity average of $90.62 \%$ $\left(w a_{1}\right)$. All land groups in research location included in land suitability classes are not suitable $(N)$ for the soybean crops development.
\end{abstract}

Key words : The carrying capacity, land potential, food crops development, Panasen sub-watershead

\section{ABSTRAK}

Tujuan penelitian ialah untuk : Menganalisis daya dukung lahan berdasarkan produktivitas tanaman pangan di Wilayah Sub DAS Panasen Kabupaten Minahasa, Menganalisis Kelas kesesuaian lahan untuk pengembangan tanaman pangan di Wilayah Sub DAS Panasen Kabupaten Minahasa, Mengetahui seberapa luas potensi lahan yang dapat digunakan untuk pengembangan tanaman pangan di Wilayah Sub DAS Panasen Kabupaten Minahasa dan Memetakan potensi lahan skala 1: 50.000 untuk pengembangan tanaman pangan di Wilayah Sub DAS Panasen Kabupaten Minahasa. Metode penelitian adalah metode survey, metode overlay (tumpang susun) digunakan untuk membuat peta grup lahan berdasarkan peta lereng, peta penggunaan lahan dan peta tanah. Metode matching digunakan untuk menentukan kelas kesesuaian lahan dan luas potensi lahan masing-masing tanaman pangan. Metode statistika digunakan untuk menganalisis dayadukung lahan pertanian. Hasil penelitian menunjukan bahwa daya dukung lahan pertanian adalah 2,93, termasuk kelas I $(\sigma>2,47)$ artinya lahan pertanian di kawasan Sub DAS Panasen telah mampu swasembada pangan dan mampu memberikan kehidupan yang layak bagi penduduknya. Potensi lahan untuk arahan pengembangan tanaman pangan adalah tanaman padi sawah adalah 3.095,10 ha yang terdiri dari kelas kesesuaian lahan $\mathrm{S} 3 \mathrm{wa}_{2} \mathrm{rc}_{1}$ dengan luas lahan 1.777,07 ha dan kelas $\mathrm{S} 3 \mathrm{wa}_{2}$ dengan luas lahan 1.318,03 ha . Tanaman jagung adalah $1.961,14$ ha terdiri dari kelas kesesuaian lahan S3wa luas lahan 755,52 ha dan kelas $\mathrm{S} 3 \mathrm{wa}_{1}, \mathrm{rc}_{1}$ dengan luas lahan 1.205,62 ha. Faktor pembatas terberat adalah curah hujan rata-rata 2.357,2 $\mathrm{mm} /$ tahun $\left(\mathrm{wa}_{1}\right)$, tekstur tanah agak kasar/lempung berpasir $\left(\mathrm{rc}_{1}\right)$. Tanaman ubi kayu adalah 1961,14 ha yang terdiri dari kelas kesesuaian lahan $\mathrm{S}_{2} \mathrm{wa}_{1},_{2}$ dengan luas lahan 755,52 ha dan kelas S3tc dengan luas lahan 1.205,62 ha. Faktor pembatas terberat adalah curah hujan rata-rata $2.357,2 \mathrm{~mm} /$ tahun $\left(\mathrm{wa}_{1}\right)$, jumlah bulan kering berturut-turut 1,41 bulan/tahun $\left(\mathrm{wa}_{2}\right)$, suhu udara rata-rata $21,8{ }^{\circ} \mathrm{C}(\mathrm{tc})$. Tanaman ubi jalar adalah 1961,14 ha dengan kelas kesesuaian lahan S3wa . Faktor pembatas terberat kelembaban udara rata-rata $90,62 \%$ (wa $)_{1}$. Semua grup lahan yang terdapat di lokasi penelitian memiliki kelas kesesuaian lahan yang tidak sesuai (N) untuk pengembangan tanaman kedelai.

Kata kunci : Daya dukung lahan, potensi lahan, pengembangan tanaman pangan 


\section{PENDAHULUAN}

Komoditas padi sawah, jagung, ubi kayu, dan ubi jalar dan kedelai merupakan komoditi yang memiliki potensi untuk dikembangkan karena merupakan komoditi penghasil bahan pangan utama dan banyak diminati masyarakat. Kandungan gizi untuk setiap 1 kilogram beras giling memiliki kandungan protein $70 \mathrm{~g}$, lemak $7 \mathrm{~g}$, dan karbohidrat $790 \mathrm{~g}$; jagung mengandung protein 92 gram, lemak 39 gram, karbohirat 734 gram; ubi jalar mengandung 18 gram protein, 7 gram lemak, 279 gram karbohidrat; ubi kayu mengandung 68 gram protein, 7 gram lemak, 378 gram karbohidrat (Danarti dan Najiyati, 1998), biji kedelai memiliki kandungan protein 30-40 \%, kadar lemak $18 \%$ dan karbohirat 35 $\%$ (Suprapto, 1999).

Berdasarkan Peta kemiringan lereng Kabupaten Minahasa, lahan pertanian yang terletak di wilayah Sub DAS Panasen memiliki variasi kemiringan lereng yaitu datar (0-8\%) hingga curam (> 25\%) (RTRW Minahasa, 2011-2031). Dengan demikian maka pemanfaatan lahan petanian harus berdasarkan kaidah-kaidah konservasi tanah dan air.

Peningkatan jumlah penduduk menyebabkan kebutuhan lahan untuk pertanian maupun pemukiman menigkat. Akibatnya adalah terjadi konversi lahan yang subur menjadi kawasan pemukiman, pemanfaatan lahan yang terdapat di lereng-lereng gunung atau lahan-lahan yang masih berupa hutan.

Pemanfaatan lahan untuk tanaman pangan yang karakteristik lahannya tidak sesuai dengan persyaratan tumbuh tanaman dapat menurunkan daya dukung lahan di kawasan Sub DAS Panasen. Meminimalisir kondisi tersebut maka diperlukan suatu tindakan evaluasi lahan.

Tujuan penelitian ialah untuk a. Menganalisis daya dukung lahan berdasarkan produktivitas tanaman pangan di Wilayah Sub DAS Panasen Kabupaten Minahasa, b. Menganalisis Kelas kesesuaian lahan untuk pengembangan tanaman pangan di Wilayah Sub DAS Panasen Kabupaten Minahasa, c. Mengetahui seberapa luas potensi lahan yang dapat diarahkan untuk pengembangan tanaman pangan di Wilayah Sub DAS Panasen Kabupaten Minahasa dan d. Memetakan potensi lahan skala 1: 50.000 untuk arahan pengembangan tanaman pangan di Wilayah Sub DAS Panasen Kabupaten Minahasa.

\section{METODOLOGI PENELITIAN}

\section{Lokasi dan Waktu}

Wilayah Sub DAS Panasen memiliki batas-batas yaitu sebelah utara berbatasan dengan Kecamatan Remboken, Kecamatan Kawangkoan, Kecamatan Kawangkoan Barat, sebalah selatan dengan sub DAS Noongan, sebelah timur berbatasan dengan Danau Tondano dan sebelah barat berbatasan dengan Gunung Rindengan, Gunung Soputan. Sub DAS Panasen memiliki luas $6.374,76$ ha atau $63,7476 \mathrm{~km}^{2}$. Penelitian ini dilaksanakan pada Bulan Pebruari hingga Bulan Juli 2015.

\section{Alat dan Bahan}

Alat-alat yang digunakan meliputi yaitu meteran, sekop, timbangan analitik, oven listrik, dan kamera digital, GPS, klinometer, kompas dan alat tulis menulis, komputer dengan sofware pendukung mikrosoft office exel 2007 dan ARC. VIEW GIS 3.3 untuk pengolahan data secara digital.

Bahan-bahan yang digunakan adalah peta rupa bumi Indonesia lembar Langowan 2417-21 tahun 1991, peta administratif Kabupaten Minahasa, peta lereng, peta Geologi, peta jenis tanah, peta penggunaan lahan, peta tingkat bahaya erosi, dan bahan-bahan laboratorium untuk analisis tanah.

\section{Kebutuhan Data}

1. Data Sekunder

Data sekunder yang digunakan adalah : tingkat bahya erosi (Murdiyanto, 2011), suhu udara $\left({ }^{\circ} \mathrm{C}\right)$ Tahun 2004-2013, kelembaban udara relative (\%) Tahun 2004-2013 (BPS Minahasa, 2014), curah hujan (mm) Tahun 2003-2014 (BP3K Noongan, 2015); kedalaman efektif $(\mathrm{cm})$, batuan di permukaan (\%), singkapan batuan (\%) (Suoth,2001).

Data sekunder yang digunakan untuk menghitung Daya Dukung Lahan Pertanian adalah : jumlah penduduk (jiwa), luas panen (ha), produktivitas tanaman pangan (kg.beras/ha/tahun) Tahun 2014 (BPS 
Kabupaten Minahasa, 2014) dan konsumsi fisik minimum (KFM) adalah $265 \mathrm{~kg}$ beras / orang / tahun.

2. Data primer

Data primer yang digunakan adalah variable karakteristik tanah terdiri dari : tekstur tanah, , KTK liat (cmol), kejenuhan basa (KB) $(\%)$, kemasaman tanah $(\mathrm{pH}), \mathrm{C}$-oganik tanah $(\%)$, alkalinitas/ESP (\%), kemiringan lereng $(\%)$, genangan $(\mathrm{cm})$.

\section{Pelaksanaan Penelitian}

Tata laksana penelitian yaitu :

Penelitian dilaksanakan dalam tiga tahapan a. Tahap persiapan

Konsultasi dan studi pustaka. Menyiapkan peta - peta dasar terdiri dari peta lereng, peta penggunaan lahan, peta tanah dan peta RBI Lembar Langowan.

Delineasi batas Sub DAS Panasen dengan cara digitasi visual berdasarkan garis kontur dan sungai pada peta RBI Lembar Langowan nomor 2417-21Tahun 1991 skala 1: 50.000 .

Membuat peta unit lahan menggunakan metode overlay dari masing masing layer peta tanah, peta kemiringan lereng dan peta penggunaan lahan yang sudah dalam bentuk shapefile (shp.). Hasil overlay tersebut selanjutnya di potong (cliping) dengan peta batas Sub DAS Panasen. Selanjutnya Peta unit lahan tersebut dimanipulasi dengan menggunakan extention geoprocesing wizard > dissolve untuk mendapatkan peta grup lahan sebagai peta analisis.

b. Tahap kerja lapangan

Melakukan cek lapang untuk membandingkan keadaan di lapangan dengan peta tentative. Penentuan titik pengambilan sampel tanah dilakukan secara sengaja (purposive sampling/ pada satu titik yang relatif mudah dijangkau namun tetap mempertimbangkan keterwakilan untuk setiap grup lahan dengan kedalaman $0-40 \mathrm{~cm}$. Jenis sampel tanah ialah sampel tanah terusik dan analisis sampel tanah di laboratorium. Mengumpulkan data primer dan data sekunder sesuai kebutuhan.

c. Tahap pasca lapangan
Melakukan pengelompokan dan tabulasi data yang diperoleh. Menganalisis daya dukung lahan pertanian berdasarkan rasio luas panen tanaman pangan perjiwa dengan luas lahan untuk swasembada pangan perjiwa.

Menganalisis dan mengevaluasi data untuk menentukan kelas kesesuaian lahan, luas potensi lahan dan membuat peta - peta kelas kesesuaian lahan dan peta potensi lahan untuk arahan pengembangan tanaman padi sawah, jagung, ubi kayu, ubi jalar, dan kedelai. Penulisan thesis sebagai laporan hasil penelitian.

\section{Analisis Data}

Daya dukung lahan dihitung dengan menggunakan Rumus menurut Soehardjo dan Tukiran (1990) dalam Moniaga (2011),

$$
\sigma=\frac{\mathrm{X}}{\mathrm{K}}
$$

Dimana :

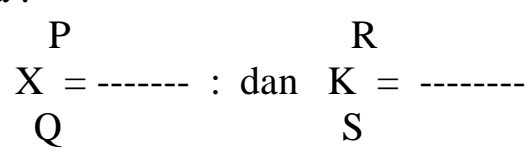

keterangan :

$\sigma$ : Tingkat daya dukung lahan pertanian,

$\mathrm{X}$ : Luas panen tanaman pangan perjiwa (ha/jiwa)

$\mathrm{K}$ : Luas lahan untuk swasembada (ha/jiwa),

$\mathrm{P}$ : Luas panen (ha)

Q : Jumlah penduduk (jiwa)

$\mathrm{R}$ : Kebutuhan Fisik Minimum (KFM $=265$ $\mathrm{kg}$ beras/orang/tahun)

$\mathrm{S}$ : Produksi tanaman pangan (kg/ha/tahun) Wilayah yang mampu untuk swasembada pangan adalah wilayah yang mampu memenuhi kebutuhan fisik minimum (KFM) sebesar 1600 kalori/orang/hari atau setara dengan $265 \mathrm{~kg}$ beras/orang/tahun.

Wilayah yang mampu untuk memberikan kehidupan yang layak bagi penduduk yang tergantung pada tanaman pangan adalah wilayah yang dapat memenuhi kebutuhan penduduk dalam taraf yang layak yaitu setara $650 \mathrm{~kg}$ beras/orang/tahun atau 2,466 kali kebutuhan fisik minimum. 
Berdasarkan nilai-nilai tersebut maka klasifikasi yang ditetapkan adalah sebagai berikut :

a. Kelas I : $\sigma>2,47$ (wilayah yang mampu swasembada pangan dan mampu memberikan kehidupan yang layak bagi penduduknya).

b. Kelas II : $1 \leq \sigma \leq 2,47$ (Wilayah yang mampu swasembada pangan tetapi belum mampu memberikan kehidupan yang layak bagi penduduknya).

c. Kelas III : $\sigma<1$ (Wilayah yang belum mampu swasembada pangan)

Analisis data spasial dan data atribut dilakukan dengan menggunakan software ArcView Gis 3.3 dengan menggunakan Extention yang sesuai dan terinstal. Kelas kesesuaian lahan ditentukan dengan menggunakan metode matching yaitu mencocokan data karakteristik lahan dengan persyaratan tumbuh tanaman dengan berpedoman pada kriteria kelas kesesuaian lahan menurut Djaenudin, dkk,. (2011).

Luas potensi lahan untuk pengembangan tanaman pangan ditentukan dengan menggunakan program Arcview GIS $3.3>>$ extension > > menu > XTools >> xtools extension-meter/hectares. Tingkat potensi lahan ditentukan berdasarkan kelas kesesuaian lahan yaitu berpotensi tinggi (kelas sangat sesuai=S1), berpotensi sedang (kelasS2), berpotensi rendah (kelas $=\mathrm{S} 3$ ).

\section{Variabel Penelitian}

Variabel penelitian yang diamati terdiri dari :

1. Daya Dukung Lahan

2. Kualitas dan Karakteristik Lahan

a) Temperatur (tc) :

- Temperatur rerata $\left({ }^{\circ} \mathrm{C}\right)$,

b) Ketersediaan Air Tawar (Wa)

- Curah Hujan (mm) pada masa Pertumbuhan,

- Kelembaban $(\%)$

- Jumlah bulan keringrata-rata

c) Media perakaran (rc)

- Tekstur,

- Kedalaman tanah $(\mathrm{cm})$,

d) Retensi hara (nr),

- KTK liat (cmol),

- Kejenuhan basa (\%),

- $\mathrm{pH} \mathrm{H}_{2} \mathrm{O}$,
- C-organik (\%),

e) Sodisitas (xn)

- Alkalinitas/ESP (\%),

f) Bahaya erosi (eh),

- Lereng (\%),(b) Bahaya erosi (TBE),

g) Bahaya banjir (fh)

- Genangan,

h) Penyiapan lahan (lp)

- Batuan di permukaan (\%),

- Singkapan batuan (\%),

\section{HASILDAN PEMBAHASAN}

Daya Dukung Lahan

Berdasarkan daya dukung lahan pada masing-masing kecamatan yang terdapat dalam kawasan sub das Panasen maka diperoleh daya dukung lahan pertanian Sub DAS Panasen adalah 2,93 termasuk kelas I karena memiliki daya dukung lahan $\sigma>2,47$. Hal ini berarti bahwa lahan pertanian di kawasan Sub DAS Panasen telah mampu swasembada pangan dan mampu memberikan kehidupan yang layak bagi penduduknya. Namun demikian untuk memenuhi kebutuhan hidupnya, telah terjadi pemanfaat lahan hutan di Kecamatan Tompaso pada kawasan dengan kemiringan lereng kelas III (15-25\%) dan IV (25-45\%) yaitu grup lahan And.III.Tgl dan And.IV.Tgl dengan luas lahan 347,39 ha sedangkan di Kecamatan Langowan Barat pada kawasan dengan kemiringan lereng $15-25 \%$ yaitu grup lahan And.III.Tgl seluas 26,21ha.

Upaya meningkatkan daya dukung dengan cara meningkatkan luas panen melalui konversi lahan hutan menjadi lahan pertanian sehingga meningkatkan bahaya erosi jika terjadi hujan. Berdasarkan peta tingkat bahaya erosi (Murdiyanto, 2011), maka tingkat bahaya erosi pada masing-masing grup lahan tersebut termasuk berat dan sangat berat dengan jumlah tanah permukaan yang hilang $1,8-4,8 \mathrm{~cm} /$ tahun dan $>4,8 \mathrm{~cm} /$ tahun.

Sarief (1985) menyatakan bahwa kerusakan hutan erat kaitanya dengan peningkatan daya dukung lingkungan yang disebabkan oleh meningkatnya jumlah penduduk dalam daerah aliran sungai. Hubungan daya dukung lahan dengan grup lahan dapat dilihat pada Gamabar 1 dan Tabel 1. 


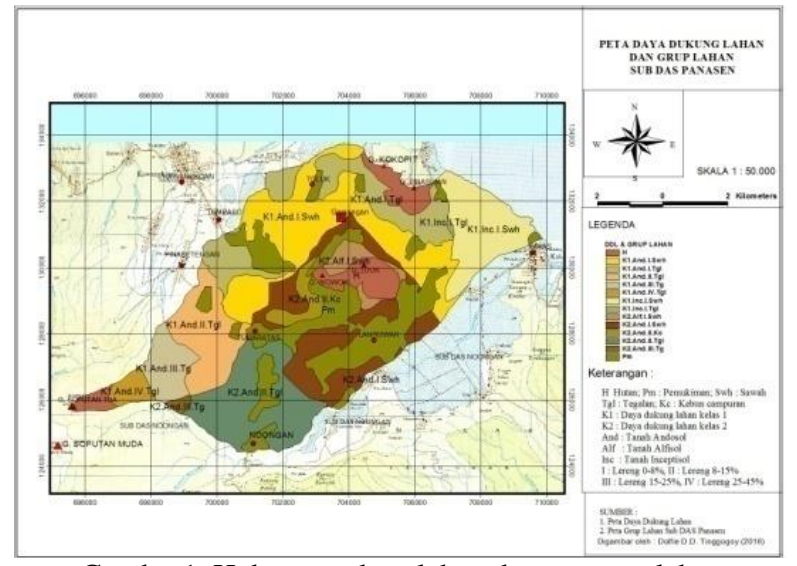

Gambar1. Hubungan daya lahan dengan grup lahan

Tabel 1. Hubungan Daya Dukung lahan dengan Grup Lahan

\begin{tabular}{lcc}
\hline \multicolumn{1}{c}{ Simbol } & $\begin{array}{c}\text { Kelas Daya } \\
\text { Dukung Lahan }\end{array}$ & $\begin{array}{c}\text { Luas } \\
\text { Lahan } \\
(\mathrm{Ha})\end{array}$ \\
\hline Pemukiman & - & $1.172,96$ \\
Hutan & - & 408,12 \\
K1.And.I.Swh & $\mathrm{K} 1=\sigma>2,47$ & $1.096,65$ \\
K1.And.I.Tgl & $\mathrm{K} 1=\sigma>2,47$ & 629,38 \\
K1.And.II.Tgl & $\mathrm{K} 1=\sigma>2,47$ & 481,57 \\
K1.And.III.Tgl & $\mathrm{K} 1=\sigma>2,47$ & 245,81 \\
K1.And.IV.Tgl & $\mathrm{K} 1=\sigma>2,47$ & 101,58 \\
K1.Inc.I.Tgl & $\mathrm{K} 1=\sigma>2,47$ & 6,78 \\
K1.Inc.I.Swh & $\mathrm{K} 1=\sigma>2,47$ & 556,26 \\
K2.Alf.I.Swh & $\mathrm{K} 2=1 \leq \sigma \geq 2,47$ & 125,61 \\
K2.And.I.Swh & $\mathrm{K} 2=1 \leq \sigma \geq 2,47$ & 640,42 \\
K2.And.II.Kc & $\mathrm{K} 2=1 \leq \sigma \geq 2,47$ & 119,36 \\
K2.And.II.Tgl & $\mathrm{K} 2=1 \leq \sigma \geq 2,47$ & 724,05 \\
K1.And.III.Tgl & $\mathrm{K} 2=1 \leq \sigma \geq 2,47$ & 26,21 \\
\hline
\end{tabular}

Sumber : Analisis peta daya dukung dan grup lahan

\section{Kelas Kesesuaian Lahan Tanaman Pangan}

Berdasarkan kelas kesesuaian lahan aktual, ditentukan kelas kesesuaian lahan potensial dengan pertimbangan bahwa faktor pembatas yang terdapat pada kelas kesesuaian lahan tersebut dapat diatasi petani dengan menerapkan tingkat manajemen sedang, maka kelas kesesuaian lahan meningkat. Jika faktor pembatas terberat tidak dapat diatasi maka kelas kesesuaian lahan potensial tetap sama dengan kelas kesesuaian lahan actual (Djaenudin, dkk., 2011). a. Tanaman padi sawah (Oryza zativa)

Hasil analisis terdapat lima kelas kesesuaian lahan potensial yaitu kelas $\mathrm{S} 3 \mathrm{wa}_{2}$ terdiri dari grup lahan 2 (Alf.I.Swh), 7 (And.I.Tgl), 16 (Inc.I.Swh ) dan 17 (Inc.I.Tgl). Kelas $\mathrm{S}_{3} \mathrm{wa}_{2} \mathrm{rc}_{1}$ adalah grup lahan 6 (And.I.Swh). Kelas $\mathrm{Neh}_{1}$ terdiri dari grup lahan 8 (And.II.Kc) dan 10 (And.II.Tgl). Kelas $\mathrm{Nrc}_{1} \mathrm{eh}_{1,2}$ adalah grup lahan 12 (And.III.Tgl). Kelas $\mathrm{Neh}_{1,2}$ adalah grup lahan 14 (And.IV.Tgl).

Faktor pembatas terberat adalah kelembaban udara rata-rata tahunan adalah 90,62 \% (wa $)^{2}$, tekstur tanah agak kasar (lempung berpasir), kasar (pasir berlempung) $\left(\mathrm{rc}_{1}\right)$, lereng $32 \%\left(\mathrm{eh}_{1}\right)$ dan tingkat bahaya erosi sangat berat $\left(\mathrm{eh}_{2}\right)$.

\section{b. Tanaman jagung (Zea mayz)}

Hasil analisis terdapat empat kelas kesesuaian lahan potensial yaitu : kelas $\mathrm{S} 3 \mathrm{wa}_{1}$ terdiri dari grup lahan 2 (Alf.I.Swh), 7 (And.I.Tgl), 8 (And.II.Kc), 16 (Inc.I.Swh) dan 17 (Inc.I.Tgl). Kelas $\mathrm{S} 3 \mathrm{wa}_{1} \mathrm{rc}_{1}$ terdiri dari grup lahan 6 (And.I.Swh) dan 10 (And.II.Tgl). Kelas $\mathrm{Nrc}_{1}$ adalah grup lahan 12 (And.III.Tgl). Kelas $\mathrm{Neh}_{1,2}$ adalah grup lahan 14 (And.IV.Tgl).

Faktor pembatas terberat curah hujan $\left(\mathrm{wa}_{1}\right)$ rata-rata $2.357,2 \mathrm{~mm} / \mathrm{tahun}$, tekstur tanah agak kasar (lempung berpasir), kasar (pasir berlempung) $\left(\mathrm{rc}_{1}\right)$, lereng $32 \%\left(\mathrm{eh}_{1}\right)$ dan tingkat bahaya erosi sangat berat $\left(\mathrm{eh}_{2}\right)$.

c. Tanaman ubi kayu

Hasil analisis terdapat lima kelas kesesuaian lahan potensial yaitu : kelas $\mathrm{S} 2 \mathrm{wa}_{1,2}$ terdiri dari 2 (Alf.I.Swh), 7 (And.I.Tgl), 16 (Inc.I.Swh), 17 (Inc.I.Tgl), 8 (And.II.Kc). Kelas $\mathrm{S} 2 \mathrm{wa}_{1},{ }_{2} \mathrm{rc}_{1}$ adalah grup lahan 6 (And.I.Swh). Kelas S3tc adalah grup lahan 10 (And.II.Tgl). Kelas $\mathrm{Nrc}_{1}$ adalah grup lahan 12 (And.III.Tgl). Kelas $\mathrm{Neh}_{1,2}$ adalah grup lahan 14 (And.IV.Tgl). Faktor pembatas terberat curah hujan $\left(w_{1}\right)$ rata-rata $2.357,2 \mathrm{~mm} /$ tahun, jumlah bulan kering berturut-turut 1,41 bulan/tahun $\left(\mathrm{wa}_{2}\right)$, tekstur tanah agak kasar (lempung berpasir), kasar (pasir berlempung) ( $\left.\mathrm{rc}_{1}\right)$, lereng $32 \%\left(\mathrm{eh}_{1}\right)$ dan tingkat bahaya erosi sangat berat $\left(\mathrm{eh}_{2}\right)$. 


\section{d. Tanaman ubi jalar}

Hasil analisis terdapat tiga kelas kesesuaian lahan potensial yaitu : kelas $\mathrm{S} 3 \mathrm{wa}_{1}$ terdiri dari grup lahan 2 (Alf.I.Swh), 6 (And.I.Swh), 7 (And.I.Tgl), 8 (And.II.Kc), 10 (And.II.Tgl), 16 (Inc.I.Swh ), 17 (Inc.I.Tgl). Kelas $\mathrm{Nrc}_{1}$ adalah grup lahan 12 (And.III.Tgl). Kelas $\mathrm{Neh}_{1,2}$ adalah grup lahan 14 (And.IV.Tgl).

Faktor pembatas terberat kelembaban udara rata-rata $90,62 \%\left(\mathrm{wa}_{1}\right)$, tekstur tanah agak kasar (lempung berpasir), kasar (pasir berlempung) $\left(\mathrm{rc}_{1}\right)$, lereng $32 \%\left(\mathrm{eh}_{1}\right)$ dan tingkat bahaya erosi sangat berat $\left(\mathrm{eh}_{2}\right)$.

\section{e. Tanaman kedelai}

Hasil analisis terdapat lima kelas kesesuaian lahan potensial yaitu : kelas $\mathrm{Nwa}_{1}$ terdiri dari grup lahan 2 (Alf.I.Swh), 6 (And.I.Swh), 7 (And.I.Tgl), 8 (And.II.Kc), 10 (And.II.Tgl), 16 (Inc.I.Swh ) dan grup lahan 17 (Inc.I.Tgl). Kelas $\mathrm{Nwa}_{1} \mathrm{rc}_{1}$ adalah grup lahan 12 (And.III.Tgl). Kelas $\mathrm{Nwa}_{1} \mathrm{eh}_{1,2}$ adalah rup lahan 14 (And.IV.Tgl). Faktor pembatas terberat adalah curah hujan yang tinggi 2.357,2 $\mathrm{mm} /$ tahun ( $\mathrm{wa}_{1}$ ), kasar (pasir berlempung) $\left(\mathrm{rc}_{1}\right)$, lereng $32 \%\left(\mathrm{eh}_{1}\right)$ dan tingkat bahaya erosi sangat berat $\left(\mathrm{eh}_{2}\right)$.

\section{Luas Poternsi Lahan Untuk Arahan Pengembangan Tanaman Pangan}

Luas potensi lahan yang dimaksud adalah luas lahan yang akan dijadikan arahan untuk pengembangan lima komoditi utama yang terdiri dari tanaman padi sawah, jagung, ubi kayu, ubi jalar dan kedelai. Lahan pertanian dengan jenis penggunaan lahan adalah padi sawah tidak akan diarahkan untuk pengembangan tanaman jagung, ubi kayu, ubi jalar dan kedelai. Berdasarkan peta penggunaan lahan pada Gambar 8 dan Tabel 24 terdapat lahan sawah permanen (intensifikasi) seluas $2.458,94$ ha atau 38,57 \% dari luas Sub DAS Panasen untuk memenuhi kebutuhan beras masyarakat yaitu grup lahan Alf.I.Swh, And.I.Swh dan Inc.I.Swh.

\section{a. Padi sawah}

Berdasarkan analisis kelas kesesuaian lahan potensial untuk tanaman padi sawah diperoleh luas lahan 3095,10 ha merupakan luas potensi lahan yang dapat diarahkan untuk tanaman padi sawah. Lahan sawah permanen (intensifikasi) seluas $2.458,94$ ha terdiri dari grup lahan Alf.I.Swh, Inc.I.Swh (kelas S3wa ${ }_{2}$ ) And.I.Swh (kelas $\mathrm{S} 3 \mathrm{wa}_{2} \mathrm{rc}_{1}$ ) dan luas lahan 636,16 ha terdiri dari grup lahan And.I.Tgl dan Inc.I.Tgl (kelas $\mathrm{S} 3 \mathrm{wa}_{2}$ ) merupakan lahan ekstensifikasi karena berpotensi untuk dijadikan lahan sawah tadah hujan. Luas lahan 1.698,58 ha memiliki kelas kesesuaian lahan yang tidak sesuai untuk pengembangan tanaman padi sawah. Peta potensi lahan dan luas lahan yang diarahkan untuk pengembangan tnaman padi sawah dapat dilihat pada Gambar 2 dan Tabel 2.

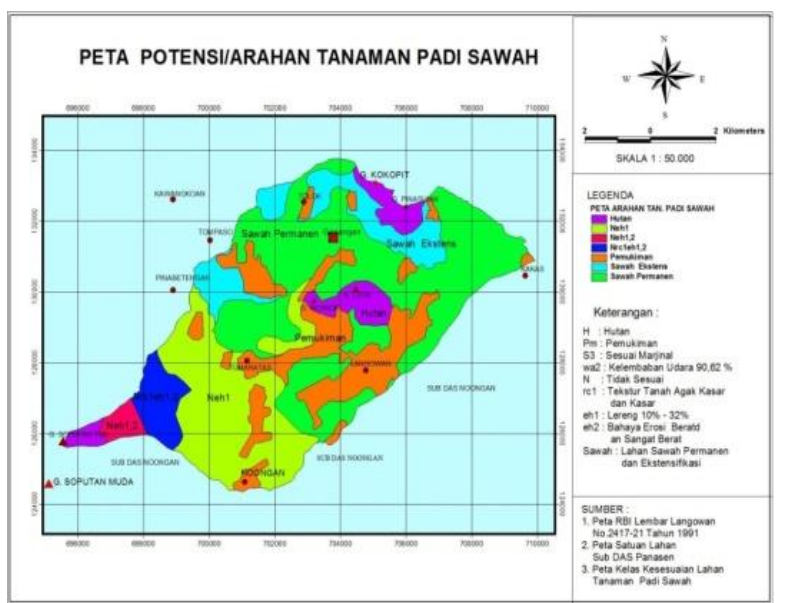

Gambar 2. Peta potensi/arahan untuk tanaman padi sawah

Tabel 2. Luas Potensi Lahan untuk Arahan Pengembangan Tanaman Padi Sawah

\begin{tabular}{c|l|c|c}
\hline No & $\begin{array}{l}\text { Potensi / } \\
\text { Arahan Lahan }\end{array}$ & $\begin{array}{c}\text { Luas } \\
(\mathrm{Ha})\end{array}$ & $\begin{array}{c}\text { Persentase } \\
(\%)\end{array}$ \\
\hline 1 & Hutan & 408,12 & 6,40 \\
\hline 2 & Pemukiman & $1.172,96$ & 18,40 \\
\hline 3 & Tidak Sesuai & $1.698,58$ & 26,65 \\
\hline 4 & $\begin{array}{l}\text { Sawah } \\
\text { Permanen }\end{array}$ & $2.458,94$ & 38,57 \\
\hline 5 & $\begin{array}{l}\text { Sawah } \\
\text { Ekstensifikasi }\end{array}$ & 636,16 & 9,98 \\
\hline & \multicolumn{1}{|c|}{ Jumlah } & $6.374,76$ & 100,00 \\
\hline
\end{tabular}

Sumber: Peta potensi / arahan lahan untuk tanaman padi sawah

\section{b. Jagung}

Berdasarkan analisis kelas kesesuaian lahan potensial untuk tanaman jagung terdapat luas lahan 1.961,14 ha terdiri dari 
grup lahan And.I.Tgl, And.II.Kc, Inc.I.Tgl (kelas S3wa ${ }_{1}$ ) dan And.II.Tgl (kelas $\mathrm{S} 3 \mathrm{wa}_{1} \mathrm{rc}_{1}$ ) dapat diarahkan untuk pengembangan tanaman jagung. Lahan yang diarahkan untuk pengembangan tanaman jagung ini memiliki faktor pembatas terberat adalah curah hujan $2.357,2 \mathrm{~mm} /$ tahun dan kelas tekstur tanah sedang dan agak kasar.

Luas lahan 2.458,94 ha merupakan lahan sawah permanen (intensifikasi). Luas lahan 373,60 ha memiliki kelas kesesuaian lahan yang tidak sesuai untuk pengembangan tanaman jagung. Peta potensi lahan dan luas lahan yang diarahkan untuk pengembangan tanaman jagung dapat dilihat pada Gambar 3 dan Tabel 3.

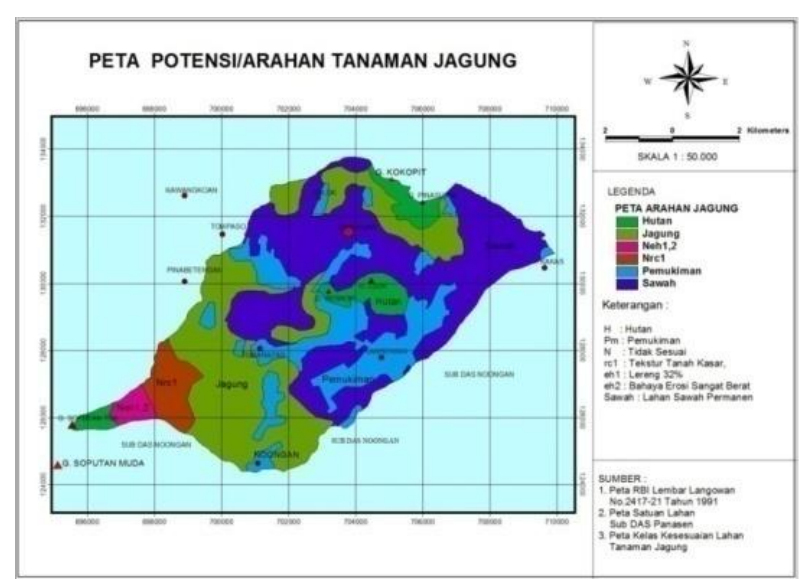

Gambar 3. Peta potensi / arahan untuk Pengembangan Tanaman Jagung

Tabel 3. Luas Potensi/Arahan Lahan untuk Tanaman Jagung

\begin{tabular}{|c|c|c|c|}
\hline $\mathrm{N}$ & $\begin{array}{l}\text { Potensi / } \\
\text { Arahan Lahan }\end{array}$ & $\begin{array}{l}\text { Luas } \\
\text { (Ha) }\end{array}$ & $\begin{array}{c}\text { Persentase } \\
(\%)\end{array}$ \\
\hline 1 & Hutan & 408,12 & 6,40 \\
\hline 2 & Pemukiman & $1.172,96$ & 18,40 \\
\hline 3 & Tidak Sesuai & 373,60 & 5,86 \\
\hline 4 & Jagung & $1.961,14$ & 30,77 \\
\hline 5 & $\begin{array}{l}\text { Sawah } \\
\text { Permanen }\end{array}$ & 2.458 .94 & 38,57 \\
\hline & Jumlah & $6.374,76$ & 100,00 \\
\hline
\end{tabular}

Sumber : Hasil Analisis Peta potensi/arahan pengembangan tanaman jagung

c. Ubi kayu

Berdasarkan analisis kelas kesesuaian lahan potensial untuk tanaman ubi kayu terdapat luas lahan $1.961,14$ ha yang terdiri dari grup lahan And.I.Tgl, And.II.Kc, Inc.I.Tgl (kelas S2 $\mathrm{wa}_{1,2}$ ) dan And.II.Tgl (kelas S3tc) dapat diarahkan untuk pengembangan tanaman ubi kayu. Lahan yang diarahkan untuk pengembangan tanaman ubi kayu ini memiliki faktor pembatas terberat adalah curah hujan $2.357,2 \mathrm{~mm} / \mathrm{tahun}\left(\mathrm{wa}_{1}\right)$, rata-rata jumlah bulan kering 1,41 bulan/tahun $\left(\mathrm{wa}_{2}\right)$ dan rata-rata suhu udara $21,8{ }^{\circ} \mathrm{C}$ (tc). Luas lahan $2.458,94$ ha merupakan lahan sawah permanen (intensifikasi). Luas lahan 373,60 ha memiliki kelas kesesuaian lahan yang tidak sesuai untuk pengembangan tanaman ubi kayu. Peta potensi lahan dan luas lahan yang diarahkan untuk pengembangan tnaman ubi kayu dapat dilihat pada Gambar 4 dan Tabel 4

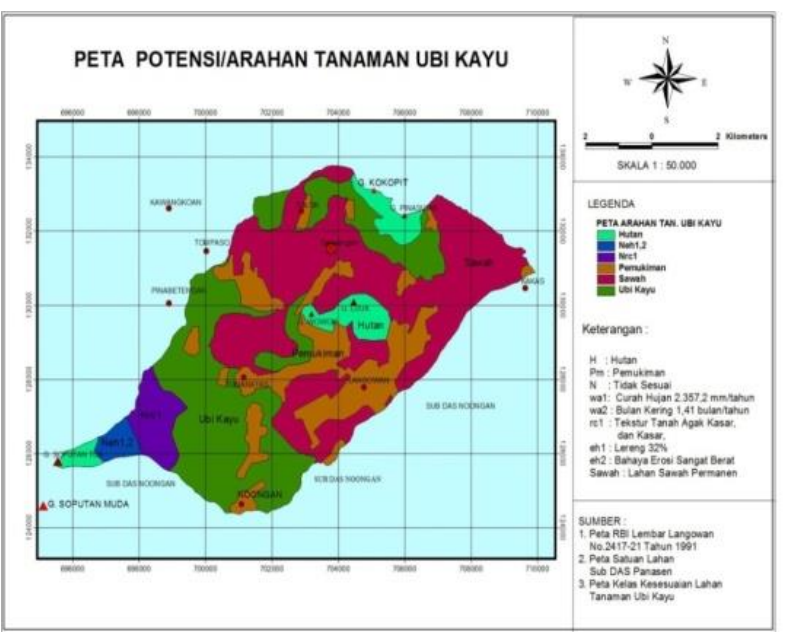

Gambar 4. Peta Potensi/Arahan untuk

Pengembangan Tanaman Ubi Kayu

Tabel 4. Luas Potensi / Arahan Lahan untuk Tanaman Ubi Kayu

\begin{tabular}{clcc}
\hline No & $\begin{array}{c}\text { Potensi/ } \\
\text { Arahan lahan }\end{array}$ & $\begin{array}{c}\text { Luas } \\
(\mathrm{Ha})\end{array}$ & $\begin{array}{c}\text { Persentase } \\
(\%)\end{array}$ \\
\hline 1 & Hutan & 408,12 & 6,40 \\
\hline 2 & Pemukiman & $1.172,96$ & 18,40 \\
\hline 3 & Ubi Kayu & $1.961,14$ & 30,77 \\
\hline 4 & Tidak Sesuai & 373,60 & 5,86 \\
\hline 5 & $\begin{array}{l}\text { Sawah } \\
\text { permanen }\end{array}$ & 2.458 .94 & 38,57 \\
\hline & Jumlah & $6.374,76$ & 100,00 \\
\hline
\end{tabular}

Sumber: Hasil Analisis Peta Potensi/Arahan Pengembangan Tanaman Ubi Kayu

d. Ubi jalar

Potensi lahan yang diarahkan untuk pengembangan tanaman ubi 
jalar adalah 1.961,14 ha terdiri dari grup lahan And.I.Tgl, And.II.Kc, Inc.I.Tgl dan And.II.Tgl (kelas S2 $\mathrm{wa}_{1}$ ). Lahan yang potensial dan diarahkan untuk pengembangan tanaman ubi jalar ini memiliki faktor pembatas terberat adalah faktor kelembaban udara $90,62 \%\left(\mathrm{wa}_{1}\right)$.

Luas lahan 2.458,94 ha merupakan lahan sawah permanen (intensifikasi). Luas lahan 373,60 ha memiliki kelas kesesuaian lahan yang tidak sesuai untuk pengembangan tanaman ubi jalar. Peta potensi lahan dan luas lahan yang diarahkan untuk pengembangan tnaman ubi lalar dapat dilihat pada Gambar 5 dan Tabel 5.

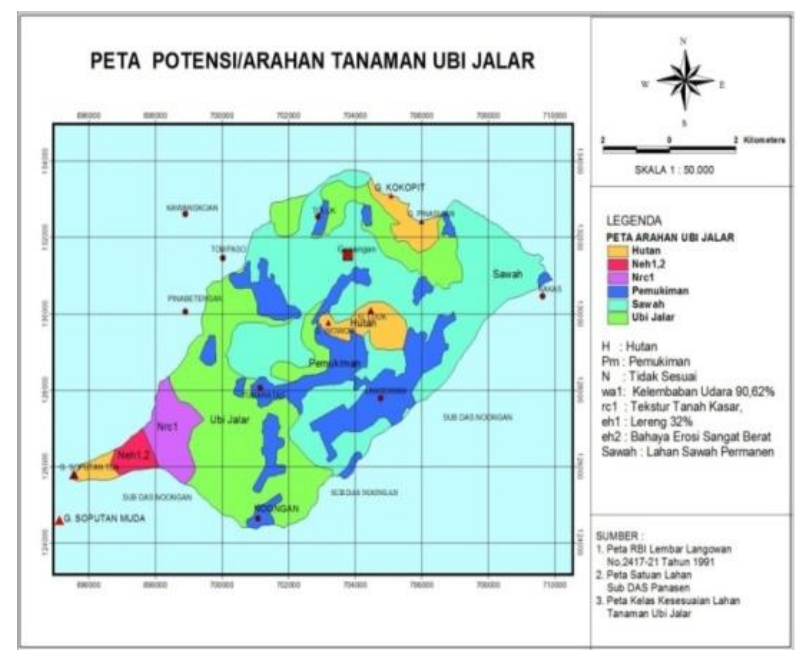

Gambar 5. Peta potensi/arahan untuk Tanaman ubi jalar

Tabel 5. Luas Potensi / Arahan Lahan untuk Tanaman Ubi Jalar

\begin{tabular}{lllc}
\hline No & $\begin{array}{c}\text { Potensi/Arahan } \\
\text { Lahan }\end{array}$ & $\begin{array}{c}\text { Luas } \\
(\mathrm{Ha})\end{array}$ & $\begin{array}{c}\text { Persentase } \\
(\%)\end{array}$ \\
\hline 1 & Hutan $(\mathrm{H})$ & 408,12 & 6,40 \\
\hline 2 & Pemukiman $(\mathrm{P})$ & $1.172,96$ & 18,40 \\
\hline 3 & Ubi Jalar & $1.961,14$ & 30,77 \\
\hline 4 & Tidak Sesuai & 373,60 & 5,86 \\
\hline 5 & Sawah Permanen & $2.458,94$ & 38,57 \\
\hline & Jumlah & $6.374,76$ & 100,00 \\
\hline
\end{tabular}

Sumber: Hasil Analisis Peta Potensi/Arahan Pengembangan Tanaman Ubi Jalar

\section{e. Kedelai}

Luas lahan 4.793,68 ha memiliki kelas kesesuaian lahan yang tidak sesuai $(\mathrm{N})$ yaitu
$\mathrm{Nwa}_{1}, \mathrm{Nwa}_{1} \mathrm{eh}_{1,2}$ dan $\mathrm{Nwa}_{1} \mathrm{rc}_{1}$. Faktor pembatas adalah curah hujan 2.357,2 $\mathrm{mm} / \mathrm{tahun}$ (wa ${ }_{1}$ ), kelas tekstur kasar (pasir berlempung) $\left(\mathrm{rc}_{1}\right)$, kemiringan lereng $32 \%\left(\mathrm{eh}_{1}\right)$ dengan tingkat bahaya erosi sangat berat $\left(\mathrm{eh}_{2}\right)$. Penggunaan lahan untuk pemukiman 1.172,96 ha dan hutan 408,12 ha. Lahan pertanian di Wilayah Sub DAS Panasen tidak disarankan untuk pengembangan tanaman kedelai. Peta potensi lahan dan luas lahan yang diarahkan untuk pengembangan tnaman ubi lalar dapat dilihat pada Gambar 6 dan Tabel 6.

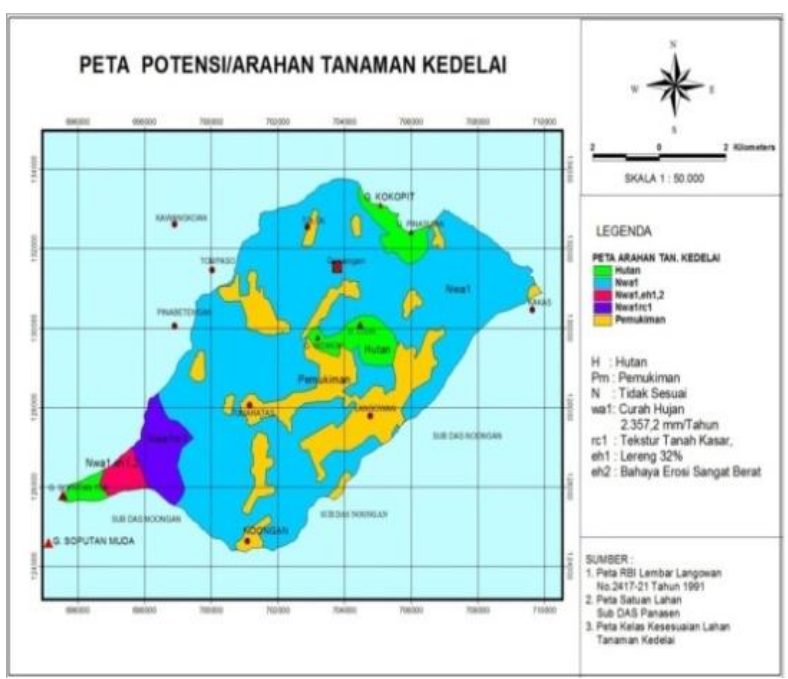

Gambar 6. Peta potensi/Arahan untuk Tanaman Kedelai

Tabel 6. Luas Potensi/Arahan Lahan Tanaman Kedelai

\begin{tabular}{c|l|c|c}
\hline No & $\begin{array}{c}\text { Potensi / Arahan } \\
\text { Lahan }\end{array}$ & $\begin{array}{c}\text { Luas } \\
(\mathrm{Ha})\end{array}$ & $\begin{array}{c}\text { Persntase } \\
(\%)\end{array}$ \\
\hline 1 & Hutan $(\mathrm{H})$ & 408,12 & 6,40 \\
\hline 2 & Pemukiman $(\mathrm{P})$ & $1.172,96$ & 18,40 \\
\hline 3 & $\mathrm{Nwa}_{1}$ & $4.420,08$ & 69,34 \\
\hline 4 & $\mathrm{Nwa}_{1} \mathrm{eh}_{1,2}$ & 101,58 & 1,59 \\
\hline 5 & $\mathrm{Nwa}_{1} \mathrm{rc}_{1}$ & 272,02 & 4,27 \\
\hline & \multicolumn{1}{|c}{$\mathrm{Jumlah}_{1}$} & $6.374,76$ & 100,00 \\
\hline
\end{tabular}

Sumber: Hasil Analisis Peta Potensi/Arahan Pengembangan Tanaman Kedelai

\section{KESIMPULAN DAN SARAN}

\section{Kesimpulan}

\section{Daya Dukung Lahan}

Lahan pertanian di kawasan sub daerah aliran sungai Panasen memiliki daya dukung lahan 2,93 dan termasuk kelas I karena $\sigma>$ 
2,47, artinya berdasarkan produktivitas tanaman pangan setara beras maka kawasan sub DAS Panasen telah mampu swasembada pangan dan mampu memberikan kehidupan yang layak bagi penduduknya. Produktivitas setara beras adalah $2,93 \times 265 \mathrm{~kg}=776,95 \mathrm{~kg} / \mathrm{jiwa} /$ tahun. untuk memenuhi kebutuhan hidupnya, telah terjadi pemanfaat lahan hutan pada lereng kelas III (15-25\%) dan IV (25-45\%) yaitu grup lahan And.III.Tgl dan And.IV.Tgl.

\section{Kelas kesesuaian lahan}

a. Padi Sawah (Oryza sativa)

Terdapat lima kelas kesesuaian lahan potensial yaitu kelas $\mathrm{S} 3 \mathrm{wa}_{2}$, kelas $\mathrm{S} 3 \mathrm{wa}_{2} \mathrm{rc}_{1}$, kelas $\mathrm{Neh}_{1}$, kelas $\mathrm{Nrc}_{1} \mathrm{eh}_{1,2}$, kelas $\mathrm{Neh}_{1,2}$. Faktor pembatas terberat adalah kelembaban udara rata-rata tahunan adalah 90,62\% $\left(\mathrm{wa}_{2}\right)$, tekstur tanah agak kasar (lempung berpasir), kasar (pasir berlempung) $\left(\mathrm{rc}_{1}\right)$, lereng $32 \%\left(\mathrm{eh}_{1}\right)$ dan tingkat bahaya erosi sangat berat $\left(\mathrm{eh}_{2}\right)$.

b. Jagung (Zea mayz)

Terdapat empat kelas kesesuaian lahan potensial yaitu : kelas $\mathrm{S} 3 \mathrm{wa}_{1}$ kelas $\mathrm{S} 3 \mathrm{wa}_{1} \mathrm{rc}_{1}$, kelas $\mathrm{Nrc}_{1}$, kelas $\mathrm{Neh}_{1,2}$. Faktor pembatas terberat curah hujan $\left(\mathrm{wa}_{1}\right)$ rata-rata $2.357,2$ $\mathrm{mm} / \mathrm{tahun}$, tekstur tanah agak kasar (lempung berpasir), kasar (pasir berlempung) $\left(\mathrm{rc}_{1}\right)$, lereng $32 \%\left(\mathrm{eh}_{1}\right)$ dan tingkat bahaya erosi sangat berat $\left(\mathrm{eh}_{2}\right)$.

c. Tanaman ubi kayu

Terdapat lima kelas kesesuaian lahan potensial yaitu : kelas $\mathrm{S}_{2} \mathrm{wa}_{1,2}$, kelas $\mathrm{S} 2 \mathrm{wa}_{1,2} \mathrm{rc}_{1}$, kelas S3tc, kelas $\mathrm{Nrc}_{1}$, kelas $\mathrm{Neh}_{1,2}$. Faktor pembatas terberat curah hujan $\left(\mathrm{wa}_{1}\right)$ rata-rata $2.357,2 \mathrm{~mm} /$ tahun, jumlah bulan kering berturut-turut 1,41 bulan/tahun $\left(\mathrm{wa}_{2}\right)$, tekstur tanah agak kasar (lempung berpasir), kasar (pasir berlempung) $\left(\mathrm{rc}_{1}\right)$, lereng $32 \%\left(\mathrm{eh}_{1}\right)$ dan tingkat bahaya erosi sangat berat $\left(\mathrm{eh}_{2}\right)$.

d. Ubi jalar

Terdapat tiga kelas kesesuaian lahan potensial yaitu : kelas $\mathrm{S} 3 \mathrm{wa}_{1}$ kelas $\mathrm{Nrc}_{1}$, kelas $\mathrm{Neh}_{1,2}$. Faktor pembatas terberat kelembaban udara rata-rata 90,62\% ( $\left.\mathrm{wa}_{1}\right)$, tekstur tanah kasar (pasir berlempung) $\left(\mathrm{rc}_{1}\right)$, lereng $32 \%\left(\mathrm{eh}_{1}\right)$ dan tingkat bahaya erosi sangat berat $\left(\mathrm{eh}_{2}\right)$.

\section{e. Tanaman kedelai}

Terdapat tiga kelas kesesuaian lahan potensial yaitu : kelas $\mathrm{Nwa}_{1}$, kelas $\mathrm{Nwa}_{1} \mathrm{rc}_{1}$, kelas $\mathrm{Nwa}_{1} \mathrm{eh}_{1,2}$. Faktor pembatas terberat adalah curah hujan yang tinggi 2.357,2 $\mathrm{mm} /$ tahun ( $\mathrm{wa}_{1}$ ), kasar (pasir berlempung) $\left(\mathrm{rc}_{1}\right)$, lereng $32 \%\left(\mathrm{eh}_{1}\right)$ dan tingkat bahaya erosi sangat berat $\left(\mathrm{eh}_{2}\right)$.

3. Luas Poternsi Lahan Untuk arahan Pengembangan Tanaman Pangan

a. Padi sawah

Luas lahan pertanian yang diarahkanuntuk pengembagan tanaman padi sawah adalah $3.095,10$ ha yang terdiri dari kelas kesesuaian lahan $\mathrm{S} \mathrm{wa}_{2} \mathrm{rc}_{1}$ dengan luas lahan 1.777,07 ha dan kelas $\mathrm{S}_{3} \mathrm{wa}_{2}$ dengan luas lahan 681,87 ha adalah sawah permanen (intensifikasi). Kelas kesesuaian lahan $\mathrm{S}_{3} \mathrm{wa}_{2}$ dengan luas 636,16 ha adalah lahan ekstensifikasi.

b. Jagung

Luas lahan pertanian yang diarahkan untuk pengembagan tanaman jagung adalah $1.961,14$ ha terdiri dari kelas kesesuaian lahan $\mathrm{S} 3 \mathrm{wa}_{1}$ luas lahan 755,52 ha dan kelas $\mathrm{S} 3 \mathrm{wa}_{1}, \mathrm{rc}_{1}$ dengan luas lahan 1.205,62 ha. Faktor pembatas terberat adalah curah hujan rata-rata $2.357,2 \mathrm{~mm} /$ tahun $\left(\mathrm{wa}_{1}\right)$, tekstur tanah agak kasar/lempung berpasir $\left(\mathrm{rc}_{1}\right)$.

c. Ubi kayu

Luas lahan pertanian yang diarahkan untuk pengembagan tanaman ubi kayu adalah 1961,14 ha yang terdiri dari kelas kesesuaian lahan $\mathrm{S} 2 \mathrm{wa}_{1,2}$ dengan luas lahan 755,52 ha dan kelas S3tc dengan luas lahan $1.205,62$ ha. Faktor pembatas terberat adalah curah hujan rata-rata 2.357,2 $\mathrm{mm} /$ tahun $\left(\mathrm{wa}_{1}\right)$, jumlah bulan kering berturut-turut 1,41 bulan/tahun $\left(\mathrm{wa}_{2}\right)$, suhu udara rata-rata $21,8^{\circ} \mathrm{C}$ (tc). 4 .

d. Ubi jalar

Luas lahan pertanian yang diarahkan untuk pengembagan tanaman ubi jalar adalah 1961,14 ha dengan kelas kesesuaian lahan $\mathrm{S}_{3} \mathrm{wa}_{1}$. Faktor pembatas terberat kelembaban udara rata-rata $90,62 \%\left(\mathrm{wa}_{1}\right)$.

e. Kedelai

Semua grup lahan yang terdapat di lokasi penelitaian memiliki kelas kesesuaian lahan 
yang tidak sesuai $(\mathrm{N})$ untuk pengembangan tanaman kedelai.

\section{Saran}

Daya dukung lahan kelas I $(\sigma>2,47)$ termasuk daerah yang telah swasembada beras dan mampu memberikan kehidupan yang layak bagi penduduknya. Upaya yang harus dilakukan adalah mempertahankan kelas daya dukung lahan melalui intensifikasi pada lahan sawah dan tegalan. Ekstensifikasi pada lahan pegunungan dapat menurunkan daya dukung.

Pemanfaatan lahan untuk pengembangan tanaman padi sawah, jagung, ubi kayu dan ubi jalar pada lahan yang sesuai harus dilakukan dengan menerapkan sisitem pertanian konsevasi dengan metode mekanis dan vegetatif.

Pemanfaatan lahan untuk tanaman kedelai di Kawasan Sub-DAS Panasen sebaiknya tidak dilakukan karena berdasarkan hasil evaluasi dinyatakan tidak sesuai $(\mathrm{N})$.

Pemilihan jenis tanaman pangan yang akan dibudidayakan harus mempertimbangkan dua hal pokok yaitu secara ekonomi menguntungkan dan secara ekologis berkelanjutaan.

Lahan yang termasuk kelas tidak sesuai sebaiknya digunakan untuk hutan produksi atau hutan lindung.

\section{DAFTAR PUSTAKA}

Asdak, Ch., 2002. Hidrologi dan Pengelolaan Daerah Aliran Sungai. Gadjah Mada University Press, Yogyakarta.

Badan Pusat Statistik Kabupaten Minahasa, 20042014. Minahasa Dalam Angka. http : minahasakab.bps.go.id/.

Jumin, H.B., 1988. Dasar-Dasar Agronomi.

Cetakan I. C.V. Rajawali, Jakarta.

Laboratorium Fisika, Kimia dan kesuburan Tanah Universitas Sam Ratulangi Manado, 2015. Hasil Analisis Sifat Kimia dan Fisik Tanah Sub DAS Panasen.

Lamina, 1989. Kedelai dan Pengembangannya. C.V. Simplex, Jakarta.

Mega, I.M, Dibia I.N, Ratna Adi, I.G.P dan Kusmiyarti, T.B., (2010). Klasifikasi Tanah dan Kesesuaian Lahan. Buku
Ajar. Fakultas Pertanian

Universitas Udayana, Denpasar.

Moniaga, V.R.B., 2011. Analisis Daya Dukung Lahan Pertanian. ASE Volume 7,Nomor 2, hal 61- 68. Mei 2011.http://ejournal.unsrat.ac.id/index.ph p/jisep/article/dow nload/

Peraturan Menteri Negara Lingkungan Hidup No. 17 Tahun 2009. Pedoman Penentuan Daya Dukung Lingkungan Hidup Dalam Penetaan Ruang Wilayah. Sekretariat Kementerian Negara Lingkungan Hidup, Jakarta.

Ritung. S, Wahyunto, Agus F, Hidayat H. 2007. Panduan Evaluasi Kesesuaian Lahan dengan Contoh Peta Arahan Penggunaan Lahan Kabupaten Aceh Barat. Balai Penelitian Tanah dan World Agroforestry Centre (ICRAF), Bogor.

Sarief, E.S., 1988. Konservasi Tanah dan Air. Balai Pustaka, Jakarta.

Sitorus, R.D., 1985. Evaluasi Sumber Daya Lahan. Tarsito, Bandung. Soil Survey Staff, 1999. Soil Taxonomy. A Basic System for Making and Interpreting Soil Surveys. Second Edition, 1999. USDASCS Agric.

Sugeng, H.R., 2001. Bercocok tanam Padi. CV Aneka Ilmu, Semarang.

Sumarno, 1984. Kedelai Dan Cara Budidayanya. CV.Yasaguna, Jakarta.

Suoth, G.F.E., 2001. Kesesuaian Lahan Untuk Tanaman Cengkeh (Eugenia aromatika) Pada Sub DAS Noongan dan Panasen Kabupaten Minahasa Propinsi Sulawesi Utara. Program Pasca Sarjana Universitas Gajah Mada, Yogyakarta.

Suprapto, 1999. Bertanam Kedelai. Penebar Swadaya, Jakarta.

Sutedjo, M.M. dan Kartasapoetra, A.G., 1987. Teknologi Konservasi Tanah dan Air. PT Bina Aksara, Jakarta.

Tadjang, M.H.L dan Mandung, S., 1988. DasarDasar Klimatologi. Jurusan Budidaya Tanaman Fakultas Pertanian Universitas Hasanudi Makasar.

Undang-Undang Republik Indonesia No. 32 Tahun 2009 Tentang Perlindungan dan Pengelolaan Lingkungan Hidup. 